\title{
THE PUBLIC INVESTMENT IN ATOMIC POWER DEVELOPMENT
}

\author{
Richard A. TYвout*
}

From the outset, the development of commercial atomic power has been a statutory responsibility of the United States Atomic Energy Commission. For the first seven years of its existence, the Commission operated under a declaration of policy which emphasized the development and utilization of atomic energy to improve the public welfare and increase the standard of living, with prior concern only for national security. ${ }^{1}$ Five programs were prescribed in the organic legislation of 1946 , the first three of which directed the Commission to assist research and development and the dissemination of information to encourage scientific progress. Medical, agricultural, and industrial progress were envisaged. 2 The framework for acquisition of basic facts on matters of peaceable interest was clearly established. And specific provisions were included to bring industrial applications to the attention of Congress when their social effects could be more accurately assessed. ${ }^{3}$

Operating under the 1946 legislation, the Atomic Energy Commission rose to second place among federal agencies with respect to expenditures upon research and development, a position which it continues to hold. In fiscal year 1953, the AEC obligated expenditures of $\$ 204$ million for this purpose. ${ }^{4}$ The Department of Defense held a clear first place with obligated expenditures of $\$$ r.48 billion out of the total federal budget allocation of approximately \$r.92 billion, while the Department of Agriculture held a lagging third place with $\$ 56$ million. All research and development expenditures for all purposes are included-defense expenditures for military purposes, agricultural expenditures for peaceful aims, and atomic energy expenditures on a middle ground oriented toward both military and peaceful objectives. Although a mainstay in our defense efforts, atomic energy development has been conducted in accordance with a relatively new and commendable idea-that is, to develop at public initiative, from defense technologies, such commercial and peaceful applications as hold reasonable promise of improving the standard of living.

Commercial (and military) applications are the end products of a series of research activities of increasing specificity. At the earliest and most general level is basic

* Ph.D. (in Economics), 1952, University of Michigan. Assistant Professor, Department of Economics, The Ohio State University. Author of the forthcoming Government Contractino in Atomic Enency. Contributor to periodicals.

${ }^{1} 60$ STAT. 755, 42 U.S.C. \$1801 (1946).

${ }^{2}$ See Report on Atomic Energy Act of 1946, S. REp. No. 1211, 79th Cong., 2d Sess. (1946).

${ }^{3} 60$ STAT. 764,42 U.S.C. $\$ 1807$ (b) (1946).

- National Science Foundation, 3 Federal Funds for Science, Selected Analyses of the Current Budget, pt. 2, at 4 (I954). This source does not include single nonrecurring items, such as laboratory or other installations, because they suggest sizable fluctuations in research programs which, in fact, do not occur. 
research, the main objective of which is simply to learn the laws of nature. Next is applied research, which seeks to apply natural laws to the solution of practical problems, commercial or otherwise. If sufficiently promising solutions are found in the laboratory, experimentation is carried into model plants called pilot plants. This stage, known as development, shifts the research emphasis from the scientific to engineering problems. Finally, full-scale production installations are built, and in the process of operating these, further knowledge is gained.

Research and development that contributes to economic atomic power has proceeded at the first two levels since the Commission assumed responsibility for the atomic energy program in 1947 and had been conducted for years before that time. Developmental work upon reactors evolved under the AEC, at first jointly for military and civil objectives, and more recently for these categories separately. Now, we have reached the stage of building a full-scale atomic power station for the generation of electricity. In the course of research and development at all levels, which is continuing apace upon problems related to and unrelated to atomic power, the Commission has tapped a wide range of academic fields-physics, chemistry, metallurgy, engineering, biology, and medicine-to name only the most popular. Numerous individual scholars throughout the country hold AEC research contracts. University projects financed by contracts with the Commission play a key part. Extensive integrated research programs are conducted at the three National Laboratories, ${ }^{5}$ at the National Reactor Testing Stations, ${ }^{6}$ and at many other AEC and private laboratories operated by industrial concerns under contract.

From January I, I947 through fiscal year 1955, the Commission obligated expenditures of $\$ 660$ million upon its basic and applied research programs-approximately $\$ 220$ million for biology and medicine, and $\$ 440$ million for physical research. ${ }^{7}$ Much of the knowledge gained in both areas has been necessary for atomic power and will undoubtedly continue to contribute to atomic power progress, but no allocations of cost can be made to atomic power. The purpose in obligating these expenditures was too general. Moreover, the Commission's physical science and biology and medicine programs partake sufficiently of broad educational objectives to be properly charged against the government responsibility in this area, though this view must be qualified by the fact that in fiscal year I953, the Commission's obligations incurred for physical research and biology and medicine were twenty-seven times those incurred by the National Science Foundation, ${ }^{8}$ a federal agency created

${ }^{\circ}$ Argonne (Cook County, Ill.); Brookhaven (Long Island, N.Y.); and Oak Ridge (Tenn.).

- Located at Arco, Idaho.

${ }^{7}$ These figures are calculated from obligations reported in annual appropriations requests of the AEC. They include operating expenditures and plant and equipment expenditures. Some of the latter, of course, are for facilities that will continue to be used in future years. The figures are totals of actual obligations incurred, except for operating expenses in 1955 and plant and equipment expenses in 1954, which are year-end estimates, and plant and equipment expenses in 1955, which are forecasts.

${ }^{8}$ Actual obligations of the National Science Foundation, including both operating expenses and plant and equipment expenditures, are given in National Science Foundation, 3 Federal Funds for SciENCE, op. cit. supra note 4, at 2I. Actual obligations for the two programs of the Atomic Energy Commission are given in Hearings before the Subcommittee of the House Committee on Appropriations on Independent Offices Appropriation for 1955, 83d Cong., 2d Sess., pt. 3, at 25II, 25 I8 (1954). 
solely for the purpose of giving public assistance to and promoting basic research in all of the sciences not otherwise supported. ${ }^{8}$

With the progress of science in atomic technology came statutory revision. In I954, public responsibility for the development of commercial atomic power was made more pointed. The statutory declaration in the sweeping amendments which constitute the Atomic Energy Act of 1954 gives new emphasis to peaceful applications by proclaiming them in its first sentence and by its ordering of national objectives. ${ }^{10}$ Six programs are prescribed, the first two of which roughly parallel the I946 programs for assistance of research and development, except that in the I954 legislation, they are to encourage "scientific and industrial progress,"11 rather than, as previously, the former by itself. Furthermore, a third of the six programs prescribes, to the extent consistent with national defense and public health and safety, encouragement of widespread participation in the development and utilization of atomic energy for peaceful purposes. The shift in emphasis is clear. A continuity of public policy for the assistance of peaceable research and development has brought commercial applications near fruition, and public assistance is now being carried into the industrial area itself.

\section{Reactor Development Costs}

Nuclear reactors serve both military and civil purposes. From the standpoint of our present interests, they, of course, provide heat from which electric power is generated. In their military role, they furnish the same heat, from which electric power or mechanical power can be obtained for the propulsion of submarines, aircraft, or for other military purposes. Also of military importance is the fact that nuclear reactors somewhat different technologically from power-producing reactors are used for the production of fissionable materials for atomic weapons and in the production of other materials for hydrogen bombs.

Reactor development costs representing these different ends are shown in Table I for the Atomic Energy Commission's activities from January I, 1947 through June 30, I955 and for activities in which the Commission has a public commitment through June 30, 1958. Three purposes are classified: civil electric power, military power, and general. Some reactor development costs for production of fissionable and other materials are included in the Table I figures, but to the extent that they are included, they are appropriately assigned to one of the three power categories. Costs shown in each of the first two categories are so classified because they are explicitly recognized by the Commission for one or the other purpose and are budgeted accordingly in AEC accounts. General reactor development costs are not assigned by the Commission to civil or military power, but are assigned jointly to both.

No attempt is made to anticipate whether the developmental costs incurred for

${ }^{9} 64$ STAT. 149 (1950), 42 U.S.C. $\$ 1862$ (Supp. 1952).

${ }^{10} 68$ STAT. 919, 42 U.S.C.A. \$20II (Supp. 1954).

${ }^{11} 68$ STAT. 922, 42 U.S.C.A. \$2013 (Supp. I954) (emphasis added). 
TABLE I

Atomic Energy Commission Reactor Development Costs

(In Millions of Dollars)

\begin{tabular}{|c|c|c|c|c|c|c|c|c|c|}
\hline \multirow[b]{2}{*}{ Purpose } & \multicolumn{5}{|c|}{ Costs Throtan Fiscas Yrat 1955} & \multicolumn{4}{|c|}{$\begin{array}{l}\text { Projected Costs Throdgr Fischi } \\
\text { YEAR } 1958\end{array}$} \\
\hline & $\begin{array}{c}\text { (1) } \\
\text { Operat- } \\
\text { ing }\end{array}$ & $\begin{array}{c}\text { (2) } \\
\text { Plant } \\
\text { and } \\
\text { Equipment }\end{array}$ & $\begin{array}{l}\text { (3) } \\
\text { Total }\end{array}$ & $\begin{array}{l}(4 a) \\
\text { Total C }\end{array}$ & $\begin{array}{l}\text { (4b) } \\
\text { ivil Power } \\
\text { Oosts }\end{array}$ & $\begin{array}{c}(5) \\
\text { Operat- } \\
\text { ing }\end{array}$ & $\begin{array}{c}(6) \\
\text { Plant } \\
\text { and } \\
\text { Equipment }\end{array}$ & $\begin{array}{c}\text { (7) } \\
\text { Total }\end{array}$ & $\begin{array}{l}\text { (8) } \\
\text { TotalCivil } \\
\text { Power } \\
\text { Investment }\end{array}$ \\
\hline 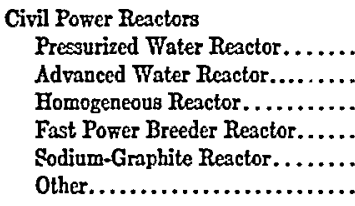 & $\begin{array}{r}17.2 \\
9.0 \\
21.3 \\
9.1 \\
5.4 \\
3.9\end{array}$ & $\begin{array}{l}6.6 \\
0.8 \\
1.0 \\
4.1 \\
- \\
0.3\end{array}$ & $\begin{array}{r}23.8 \\
9.8 \\
22.3 \\
13.2 \\
5.4 \\
4.2\end{array}$ & & & $\begin{array}{r}45.0 \\
16.0 \\
35.1 \\
22.3 \\
9.5 \\
42.5\end{array}$ & $\begin{array}{r}40.0 \\
1.0 \\
11.9 \\
17.7 \\
0.5 \\
-\end{array}$ & $\begin{array}{l}85.0 \\
17.0 \\
47.0 \\
40.0 \\
10.0 \\
42.5\end{array}$ & \\
\hline 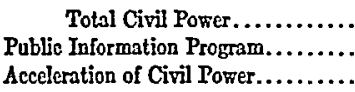 & $\begin{array}{c}65.9 \\
1.8 \\
-\end{array}$ & $\begin{array}{l}12.8 \\
-\end{array}$ & $\begin{array}{c}78.7 \\
1.8 \\
-\end{array}$ & $\begin{array}{c}78.7 \\
1.8 \\
-\end{array}$ & $\begin{array}{r}78.7 \\
1.8 \\
-\end{array}$ & $\begin{array}{c}170.4 \\
- \\
50.0\end{array}$ & $\frac{71.1}{-}$ & $\frac{241.5}{75.0}$ & $\frac{241.5}{75.0}$ \\
\hline $\begin{array}{l}\text { General Development, Operation of } \\
\text { Supportirs Facilities, etc......... }\end{array}$ & 237.6 & 181.2 & 369.0 & $\begin{array}{c}\text { Prorated } \\
74.8\end{array}$ & $\begin{array}{c}\text { Alternative } \\
\text { Cost } \\
\text { Avoidance } \\
171.8\end{array}$ & - & - & - & - \\
\hline Total Reactor Development... & 467.6 & 325.4 & 793.0 & 155.3 & 252.3 & - & - & - & - \\
\hline
\end{tabular}

Soonce: Columns (1), (2), and (3) show unpublished data from U. S. Atomic Energy Commission. The Public Information Program Fas estimated at $\$ 300,000$ per year for five years preceding June 30 , 1955 , plus $\$ 334,000$ for services given industry groups. General Development costs includes 3.5 per cent of all other operating costs for administration of all reactor development activities. Data on Civil Power Reactors listed in columns (5), (6), and (7) are from the combined sources: Jont Commiten oN ATOMTo ENERGT, REPORT

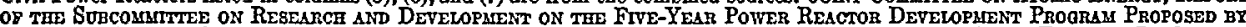
THB ATOMIC ENeroy Commssion, 83d Cong., 2d Sess. (1954); and Hearings before the Joint Commitlee on Alomic Eneroy on Detelopment, Grotetho by H. R. 6766, Public Works Appropristion Act, 1955, c. 370, 69 SrAT. 354 (1955), and H. R. 7278, Supplemental Appropriation Act, 1856 , c. 541, 69 STAT. 450 (1955).

Costs are given on an acerual basis. This means that plant and equipment costs appear only to the extent depreciation is charged and that all other costs are similarly unrelated to the time of corresponding cash disbursements.

civil power will also serve military purposes or vice versa. The important point in evaluating the public investment in civil atomic power development is the purpose for which the costs were incurred. It is common knowledge that many defense programs have given rise to commercial applications. Examples come to mind in the electronics industry, in Diesel engines, and elsewhere. In our approach, these are social windfalls, since the research and development out of which they grew was undertaken solely for defense. By contrast, the Atomic Energy Commission operates under terms of reference, as we have seen, that make clear the dual purpose of its research and development.

The first five reactor projects in Table I represent the five prongs of the Commission's current Five-Year Power Reactor Development Program, commonly known as the five-year program. This program includes four pilot plant projects. The fifth project is a full-scale power station, the pressurized water reactor, to be operated by the Duquesne Light Company, of Pittsburgh, under a cost-sharing agreement with the Atomic Energy Commission, which agreement we shall examine in greater 
detail later. Costs incurred by the Duquesne Light Company, of course, are not included in Table I.

The five-year program was formally announced in March, $19544^{12}$ although AEC research and development had built up to it in projects undertaken prior to that time. The pressurized water reactor was the natural successor to work that had been done by the Westinghouse Electric Corporation in the Commission's Bettis Laboratory at Pittsburgh, although the work had been as much for military as for civil purposes; and Westinghouse is the Commission's principal contractor for the design, development, and construction of the reactor portion of the plant. The advanced water reactor concept was initiated by Argonne National Laboratory, operated for the Commission by the University of Chicago; and the present project is the third of a series employing the same principle conducted by the Chicago group at the National Reactor Testing Station. A small model of the homogeneous reactor was started in March I95I at the Oak Ridge National Laboratory, operated for the Commission by the Union Carbide and Carbon Corporation, and was shut down and dismantled in early 1954; and the present homogeneous reactor is also being constructed at Oak Ridge. The fast power breeder reactor, like the advanced water reactor, is being designed under the direction of the University of Chicago at the National Reactor Testing Station and follows a previous model designed and operated by the University at the National Reactor Testing Station. The sodium-graphite reactor is being designed and will be operated by North American Aviation, Inc., at a location near Los Angeles. Experiments with the sodium-graphite technology have previously been conducted by North American Aviation and have grown out of other work involving a submarine reactor at the Knolls Atomic Power Laboratory in Schenectady, owned by the AEC and operated by the General Electric Company.

The cost of earlier research and development leading up to the five reactors are assigned in Commission accounts, which were the source of data in Table I, to civil atomic power only in cases where this was the clear intention at the beginning of the research. In all of the projects except the pressurized water reactor, costs incurred before fiscal year 1954 are included in cumulative totals as of the end of fiscal year 1955. Otherwise, earlier costs are included under the general or military headings, whichever is appropriate. The "Other" item in "Civil Power Reactors" shows developmental costs that are peculiar to civil power, but not to any one of the five reactor projects.

Included with the civil power reactors are the AEC public information programs directed toward the dissemination of technological information for civil atomic power and a new program, Acceleration of Civil Power, beginning in fiscal year

\footnotetext{
${ }^{12}$ See Joint Committee on Atomic Energy, Report of the Subcommittee on Research and Development on the Five-Year Power Reactor Development Program Proposed by the Atomic Energy Commission, $83 \mathrm{~d}$ Cong., 2d Sess. (1954). Progress under the program was more recently reported in Joint Committce on Atomic Energy, Current Statement of the Atomic Energy Commission on the Five-Year Renctor Development Program to the Subcommittee on Research and Development, 84th Cong., Ist Sess. (1955).
} 
1956. The public information programs include exhibits, publication aids, and services rendered by the Atomic Energy Commission in its now-terminating Industry Study Program. The latter involved an AEC cost of $\$ 344,000$ and a private cost of $\$ 4.9$ million to bring industry groups into contact with classified reactor development data. ${ }^{13}$ The acceleration program is to furnish public aid to privately proposed atomic power stations in ways that we shall note in future discussion.

The military projects to which Table I refers include, as we have seen, the development of atomic propulsion engines for submarines, naval surface vessels, and aircraft. For such uses, atomic energy offers the military advantages of a fuel that needs no replacement for years at a time. More recently, military interest has included the small "package" electric power plant operated by nuclear energy, which can be set up at remote installations-again, without the traditional logistic problems of refueling.

The general costs shown in Table I include the administration of reactor development for all purposes shown in the table; the operation of the National Reactor Testing Station, with its chemical processing and other service facilities; and a long list of advanced engineering studies of heat exchangers, compressors, valves, pumps, materials corrosion, and like matters related to the operation of power reactors. Much of the work done in early years fits neither of the other two classifications and hence appears among the general costs.

Table I shows general costs assigned to civil and military objectives by two procedures. These procedures make alternative assumptions and follow what seem to be the most applicable theories of common cost allocation for present purposes. In the first procedure, general costs have been prorated in proportion to the operating costs of civil reactor development as a percentage of the combined total operating costs of civil and military reactor development. This method treats general costs in the same way in which overhead burden is treated in many industrial cost accounting systems. In the case at hand, it assumes that the operating costs for civil atomic power development reflect the proportion in which general costs are incurred for the same purpose. This approach places general costs assignable to civil reactor development at $\$ 74.8$ million and the total civil power cost to June 30 , I955 at \$I55.3 million.

The second procedure views all costs incurred in civil reactor development, whether for operating expenses or plant and equipment, as capital investments. This view seems well suited for the general nature of research and development. General costs under this procedure, then, are regarded in much the same way as are capital costs for some of our large multi-purpose river and regional development projects, such as the Tennessee Valley Authority. On this basis, we have adopted the most satisfactory of the techniques used for allocation of multi-purpose investment costs, the "alternative cost avoidance" principle. ${ }^{14}$

\footnotetext{
${ }^{13}$ See the testimony of Dr. Willard F. Libby, member of the AEC, in Hearings before the loint Committee on Atomic Energy on Development, Growth, and State of the Atomic Energy Industry, 84th Cong., Ist Sess. 12 (1955).

${ }^{1}$ "For an extensive discussion of the methods and problems of common cost investment allocations, see Joseph S. Ransmeier, The Tennessee Valiey Authority 270-75 (I942).
} 
As applied to general reactor development costs, alternative cost avoidance recognizes savings for both military and civil purposes in the concurrent conduct of research for both. If conducted independently, each would have to incur at least some of the general costs listed in Table I. Therefore, we ask how much of these general costs each is avoiding because of the concurrent conduct of the other. The alternative cost avoidance principle assigns general costs to each purpose in proportion to the costs that purpose is avoiding.

As if to answer our question, Dr. L. R. Hafstad, Director, Division of Reactor Development, stated in $1952:^{15}$

For the immediate future, very little distinction can be made between reactors for civilian uses and reactors for military uses. In general, the same ground must be covered in order to learn how to design a power-producing reactor for any purpose.

The same is true of the costs incurred by the Atomic Energy Commission since I952, in so far as these are classified as general. ${ }^{16}$ This being the case, the costs avoided by each of the purposes are equal-military and civil power have shared alike in the general costs. The alternative cost avoidance principle, therefore, assigns $\$$ I7r.8 million, or half the general costs, to civil reactor development, giving a total civil power cost to June 30, I955 of $\$ 252.3$ million.

Also shown in Table I are costs projected by the Atomic Energy Commission through fiscal year 1958. The costs given for the five-year program reactor projects are quite firm as a result of their approval, on March 23, x954, by the Joint Committee on Atomic Energy. ${ }^{17}$ The costs shown for the acceleration program are from appropriations that have already been authorized, the $\$ 50$ million for operating expenses $^{18}$ and the $\$ 25$ million for plant and equipment. ${ }^{10}$ The Commission has estimated that acceleration program operating costs to be incurred in fiscal year r956 will be \$ro million, the balance of the $\$ 50$ million to be included in unpaid obligations at the end of the fiscal year. ${ }^{20}$ There is no doubt that the total of operating costs will be incurred by the end of fiscal year 1958, but it seems unlikely that all of the $\$ 25$ million for acceleration program plant and equipment will appear as cost before the end of fiscal year 1958 . It is all included in the Table I projected figures, however, in the absence of any more exact information and since it is committed ultimately to civil power in any event.

Figures representing commitments with anything like the assurance of those given for civil power are not available for military and general reactor projects through fiscal year 1958 , nor are such figures available for related public information costs. Impossibly low, irreducible minima for the public investment in civil atomic power

\footnotetext{
${ }^{10}$ Hearings before the Subcommittee of the Senate Committee on Appropriations on H.R. 7072, In. dependent Offices Appropriations, 1953, 82d Cong., 2d Sess. 52 (1952).

${ }^{16}$ Personal communication, Atomic Energy Commission, July 26, 1955.

${ }^{17}$ See Report, supra note 12, at 4.

${ }^{18} 69$ STAT. 354 (1955).

${ }^{10} 69$ STAT. 450 (I955).

${ }^{20}$ See prepared statement by the AEC, in Hearings before the Subcommittee of the House Committee on Appropriations on Public Works Appropriations for 1956, 84th Cong., Ist Sess. 391 (1955).
} 
could be obtained by adding to the 1958 figures the general reactor and public information costs as these stood at the end of fiscal year 1955. This would give a public investment ranging from $\$ 393$.x to $\$ 490 . \mathrm{I}$ million, but ignores the obvious fact that general costs attributable to civil power are being and will continue to be incurred beyond June 30, 1955. Moreover, we cannot exclude the possibility that another acceleration appropriation might be made before the end of fiscal year 1958 .

An alternative approach is to assume that military and general reactor costs will continue at the same rate over the next three fiscal years as they have averaged over the eight and a half years of the Commission's life ended on June 30, x955. All indications are that this will understate the actual costs, because so little was done in early years and because there has been a continuous accelerating of reactor development in recent years. This approach gives a public investment of $\$ 507$ to $\$ 55 \mathrm{I}$ million, which, in view of the conservative assumptions we have made, will probably turn out to be quite low. Rounding the figures and increasing the spread to allow for uncertainties and to offset somewhat the conservative bias, we will settle upon the range $\$ 500$ to $\$ 600$ million as a working estimate of the AEC investment in civil atomic power development by the end of June 1958 .

\section{The Decade of Development: i958-ig68}

The Atomic Energy Commission intends that the five-year program and other efforts through fiscal year 1958 will serve as important ground-breakers, but it does not feel that they will go all the way to bring competitive nuclear power. Statements of goals in civil development generally refer to nuclear power as becoming competitive at some period in time quite a few years after $195^{8}$. In July 1954, Dr. Hafstad stated $:^{21}$

Those of us in the atomic energy business feel that the cross-over point [between conventional and nuclear power costs] is likely to come somewhere between five and fifteen years from now, depending on the vigor and intensity of the development effort in the atomic energy field.

This would place the point at which civil atomic power becomes competitive with conventional power between I959 and I969, suggesting a most probable year of 1964 . Dr. Hafstad again spoke on this subject in October 1954, while discussing the depletion of national energy resources as a cause for atomic power development: ${ }^{22}$

Now, since uranium is potentially attractive as a fuel for powerplants, we have projected that within the next decade or two, a small but increasing percentage of the new central station powerplants might be nuclear. This might well happen when the pressure on oil and gas forces the liquifaction and gassification of coal.

${ }^{21}$ Remarks prepared by Lawrence R. Hafstad, Director, Division of Reactor Development, AEC, for Delivery before the Missouri Basin Inter-Agency Committee, Rapid City, S.D., AEC Release, July 2I, 1954.

${ }_{\text {22 }}$ Remarks prepared by Lawrence R. Hafstad, Director, Division of Reactor Development, AEC, to the Electric Companies Public Information Program Annual Workshop Conference, St. Louis, Mo., AEC Release, Oct. 28, I954. 
Dr. Hafstad referred to expert opinion which dated the point when oil and gas are expected to begin to be unable to meet the demand for liquid fuels at about the year $1970 .^{23}$ This suggests that the competitive level envisaged by Dr. Hafstad might come late rather than early in the I960's. Further substantiation of a late date is found in a statement by Dr. James A. Lane, of the Oak Ridge National Laboratory, at the seventy-two nation Atoms-for-Peace Conference in Geneva in August 1955, to the effect that atomic power will become competitive with conventional power within the next 15 to 20 years in the United States. ${ }^{24}$ If we seek a compromise date, even an early one out of deference to Dr. Hafstad's authority, it appears that there will pass at least a decade after $195^{8}$ before atomic power costs, by and large, become as low as electric power costs in conventional installations.

The magnitude of the research and development job yet to be done is suggested in a recent statement by W. Kenneth Davis, Director, Division of Reactor Development (Mr. Davis assumed this post in February 1955, three months after Dr. Hafstad requested a release from his AEC assignment to accept a position in private industry) $:^{25}$

Taking everything into account, I believe it is fair to say that we do not know today how to build a nuclear power plant which would produce power for much less than two to three times that from the best conventional plant of the same size which could be built instead.

In a previous address, in October I954, Mr. Davis had placed the cost of nuclear power at approximately three times that of conventional power. ${ }^{20}$ In both addresses, Mr. Davis pointed out that his estimates were for nuclear plants whose construction might start at that time, but whose date of completion would be several years laterin $195^{8}$ or 1959 .

\section{Atomic Power Stations and AEC Research Assistance}

For the decade of development from $195^{8}$ to 1968 , the Atomic Energy Commission has been concerned almost exclusively with the construction of full-scale atomic power stations, suggesting that AEC has tentatively cast around them its plans for progress. Public utility investments in atomic power appear to have been first urged by Dr. Hafstad in July, I954:27

Utility organizations, for the sake of their own education and as a contribution to the national good, should be persuaded to consider seriously substituting a few nuclear power

${ }^{23}$ There are differences of opinion among experts on this point. See generally 3 President's MAterials Policy Commission, Resources for Freedom (1952), in which many developments that would tend to keep down real fuel costs through 1975 are discussed.

${ }^{24}$ See Wall Street Journal, Aug. 10, 1955, p. I, col. 3.

${ }^{25}$ Remarks prepared by W. Kenneth Davis, Director, Division of Reactor Development, AEC, for Presentation at the Seventeenth Annual Meeting of the American Power Conference, Chicago, Ill., AEC Release, April r, 1955.

${ }^{26}$ See remarks prepared by W. Kenneth Davis, Deputy Director, Division of Reactor Development, AEC, for Presentation at the National Industrial Conference Board, New York, N. Y., AEC Release, Oct. r3, 1954.

${ }^{27}$ Remarks prepared by Lawrence R. Hafstad, supra note 21. 
plants for conventional plants in the course of normal expansion. . . . The nuclear plant will cost significantly more than a conventional plant. ... Since the utilities' first responsibility is to the customer, the higher cost of such a nuclear plant cannot strictly be justified, though the cost of the equivalent conventional plan will represent a routine expenditure. ...

A joint program might, therefore, be developed on this basis: As a first approximation the utility company proposes to provide an amount of money equal to the cost of a conventional plant for the location in question while the Atomic Energy Commission, as part of its research and development expense, finances the difference between the cost of a conventional plant and a nuclear plant.

Dr. Hafstad's joint program would increase the AEC (public) investment in atomic power development but would protect the consumer and alleviate the necessity for private capital investment in the foreseeable future of high-cost atomic power. Apparently attempting to enlist private capital investment, Dr. Hafstad told an industrial audience in September 1954, three months later $:^{28}$

The time has just about passed for industry, especially companies new to the business, to come in to Washington and get large contracts with Government money and thus learn the atomic business. Anything over and above the five-year program as it is now planned will essentially be the responsibility of industry and must be carried out with industrial money.

Later in the same address, he amplified the point: ${ }^{29}$

I think you utility people ought to come in with a proposal which shows competence, genuine interest, and real determination to carry through and learn from your experience with the new plants. There will be ways and means under the new law for the Government to help you over the hurdles and get the plants built.

In view of a subsequent statement by Mr. Davis, it seems likely that Dr. Hafstad's "ways and means" referred especially to AEC financial assistance in the conduct of research and development on tough technological problems. This is exactly what the Commission's five-year program and its acceleration program seek to accomplish, as explained by Mr. Davis in his April r955 address: ${ }^{30}$

The important matter is to make sure that we have done all we can to reinforce the technical basis for a nuclear power industry and to provide an atmosphere in which it can take root and grow....

The Atomic Energy Commission can be of considerable help in developing the basic technology and this, in fact, is the objective of the Commission's present program.

One is naturally led to ask whether public expenditures for commercial goals are indeed good public investments if made for projects which private industry will not support with its own funds. A number of points can be made in the affirmative.

\footnotetext{
${ }^{29}$ Remarks prepared by Lawrence R. Hafstad, Director, Division of Reactor Development, AEC to the Conference of the Atomic Industrial Forum, Inc., on The New Atomic Energy Law-What It Meane to Industry, New York, N. Y., AEC Release, Sept. 28, I954.

${ }^{20}$ lbid.

${ }^{30}$ Remarks prepared by W. Kenneth Davis, supra note 25.
} 
Assuming that a dollar spent on research by the Government yields the same technological results as a dollar spent on research by private industry, the former may represent a broad enough public interest in economic progress to be written off, so to speak, from resulting public benefits ${ }^{31}$ in circumstances where the latter would not be able to be written off in the patentable value of the results. ${ }^{32}$ Nonpatentable results, for example, would seem to offer no incentive for private financing of research, though we know that a certain small part of industrial research is in basic science, where the results are not patentable. The same lack of private incentive would appear to exist in research whose results are not expected to pay off except over a term longer than the duration of patent rights, or in research whose results overlap many industrial fields so that no single individual firm would sufficiently participate in the fruits of a research investment to make it pay. All of these considerationsnonpatentabilty, length of time before profitable application, and breadth of industrial consequences-apply particularly to the atomic power field and would justify a public effort in research and development. ${ }^{33}$

On the negative side of the case for public support of research and development are the difficulties of moving from the public sector to the private sector of the economy, with research and development being conducted in the former and the results employed in the latter. If private enterprise is to have free access to the research results, these results should be equally available to all. This would present difficult problems in the dissemination of information and in the education of industrial groups under any circumstances. As has been shown elsewhere, the problems are particularly aggravated in the atomic energy program by the contractual arrangements which it is necessary for the AEC to make to achieve its other goal of efficient production of special nuclear materials for national defense. ${ }^{34}$ The tendency, which the Commission would find difficult to offset if it had ample time and impossible to offset if civil atomic power is pushed into the private sector with maximum speed, is for contractors and others having an early part in work conducted at public expense to gain special advantages that will prejudice their less fortunate industrial rivals. If the public support of research and development gives special aid to certain private groups and thereby increases industrial concentration, this is a clear point in its condemnation, though we note, on balance, that privately conducted research and development, too, is often associated with industrial size and the perpetuation of industrial concentration. ${ }^{35}$

\footnotetext{
${ }^{31}$ Exactly what is involved in writing off a public expenditure will be illustrated in a later calculation for the public investment in civil atomic power development.

${ }^{32}$ It is assumed that the results of publicly financed research and development would be made generaily available for private use, whether with or without a publicly owned patent. If a patent were publicly owned, this would mean that it would be made available on a nonexclusive royalty-frce basis.

${ }^{33}$ Special rules apply for atomic energy patents, but it is not felt that these change the broad points made here. The patent problem in atomic energy is treated in another article in this symposium. Sce Boskey, Some Patent Aspects of Atomic Power Development, infra, 113-3I.

${ }^{34}$ See Tybout, The Contractor System, 290 Annals 82 (Nov. 1953). The point is developed in detail in a forthcoming book, Richard A. Tybout, Government Contracting in Atomic Eneroy.

${ }^{35}$ This, of course, is the point usually associated with the late Joseph A. Schumpeter. See JosEPH A. Schumpeter, Capitalism, Socialism, and Democracy c. 8 (2d ed. i947).
} 
To summarize, then, it appears that there are many advantages inherent in the public conduct of research and development and that the problems which it entails, though serious, especially in the atomic energy case, are problems of administration that are not insurmountable.

\section{Rate of Growth of the Nuclear Power Industry}

Some indication of the magnitude of the expected investment in atomic power facilities was given by Mr. Davis in April 1955. Mr. Davis' estimates appear in Table II under his name. He explained his approach in making the estimates as follows: $:^{38}$

In my view, we can look forward to three phases in the transition to nuclear power plants. ... During the first or "induction phase," it is anticipated that some fairly large nuclear plants will be built, largely with private funds. The Government will lend fissionable material and may finance laboratory research and development, and possibly pay for technical information resulting from development, construction, and operation of the plants.

At some point in time the degree of confidence in the eventual economic advantages of nuclear power will become so strong that a relatively large proportion of new power plants will be nuclear. This will be largely a psychological point. However, when it is reached it is not difficult to foresee the proportion of nuclear power plants to the total number being built increasing from perhaps 5 percent to 60 percent in ro years or less. Once this trend is started, the very fact of the transition itself will contribute enormously to solution of economic problems.

When the proportion of new nuclear plants reaches perhaps 6o to 70 percent, the growth may become a matter of slow saturation, since at that point the rest of new capacity will be either in very small plants or in plants located where fuel costs are exceptionally low.

The three financial aids to which Mr. Davis refers in his first paragraph are made available from appropriations in the previously noted acceleration program and constitute an important feature of AEC's current Power Demonstration Reactor Program, hereinafter called the demonstration program, in aid of atomic power stations otherwise privately financed. The two aids in the form of government-financed laboratory research and development and government payments for research and development results fit the general analysis which we have completed in immediately preceding paragraphs. The government lending of fissionable materials is a different type of public aid which draws upon AEC costs budgeted outside of Table I and will be discussed in connection with the broader topic of AEC charges and price supports.

In his second paragraph, Mr. Davis does not base the transition to nuclear power plants upon expected cost advantages, but, on the contrary, feels that cost reductions will follow as a consequence of what seems to be an expected band-wagon movement. He does not seem to contemplate public aids in the swing to nuclear plants, though in a chart presented with his remarks, he places the beginning of the up-

\footnotetext{
${ }^{30}$ Remarks prepared by W. Kenneth Davis, supra note 25 .
} 
swing in 1965 and the leveling off in 1975 . In his third paragraph, Mr. Davis clearly indicates that, in his view, nuclear power will have become competitive in a large sector of the economy by the time of leveling off, or 1975 . These predictions are roughly consistent with our previously selected 1968 date for generally competitive nuclear power. They are surprising, however, in the extent to which they seem to suggest a large investment in nuclear power before this date.

Accompanying his estimates of nuclear power capacity shown in Table II, Mr. Davis gave an estimate of 200 million installed kilowatts for total national electric generating capacity in 1965 and 400 million in 1975 . Comparing Table II, this would mean that he expects $2 \frac{1}{2}$ per cent of total electric generating capacity to be nuclear in 1965 and approximately 21 per cent to be nuclear in 1975 . By way of comparison, the President's Materials Policy (Paley) Commission estimated 300 million kilowatts of generating capacity will be required in $1975,{ }^{37}$ the Federal Power Commission has placed the figure at roughly $25^{\circ}$ million kilowatts, ${ }^{38}$ and the Edison Electric Institute forceasts a range of 301 to 423 million kilowatts. ${ }^{30}$

Mr. Davis acknowledged optimism at the time that he gave his estimates of both nuclear and total power generating capacities. In view of both this fact and the additional fact that we shall later find grounds to doubt whether such a large part of total national generating capacity can be in nuclear power plants in the years before nuclear power becomes competitive with conventional power, we have calculated

TABLE II

Installation of Atomic Power Generating Facilities

\begin{tabular}{|c|c|c|}
\hline \multirow[b]{2}{*}{ Year } & \multicolumn{2}{|c|}{$\begin{array}{l}\text { Installed Atomic Powen Capacity, } \\
\text { Mrinions of KilowatTs }\end{array}$} \\
\hline & Davis Estimates & FPC-Lane Estimates \\
\hline $\begin{array}{l}1960 \ldots \ldots \ldots \ldots \ldots \\
1965 \ldots \ldots \ldots \ldots \ldots \\
1970 \ldots \ldots \ldots \ldots \ldots \\
1975 \ldots \ldots \ldots \ldots \ldots \\
1980 \ldots \ldots \ldots \ldots \ldots \\
1985 \ldots \ldots \ldots \ldots \ldots \ldots \\
1990 \ldots \ldots \ldots \ldots \ldots \\
1995 \ldots \ldots \ldots \ldots \ldots \ldots \\
2000 \ldots \ldots \ldots \ldots \ldots\end{array}$ & $\begin{array}{r}2 \\
5 \\
27 \\
83 \\
175 \\
\cdots \\
\cdots \\
\cdots \\
\cdots\end{array}$ & $\begin{array}{r}0.5 \\
5.0 \\
12.0 \\
20.5 \\
31.5 \\
45.0 \\
61.0 \\
79.5 \\
100.5\end{array}$ \\
\hline
\end{tabular}

Sompe: Davis estimates are from Remarks by W. Kenneth Davis, Director, Division of Reactor Development, at the Soventcenth Annual Meeting of the American Power Conference, Chicago, IIl., AEC Press Release, April 1, 1055. Mr. Davis' estimates ara for tho year's end in each case.

year's end in each case.

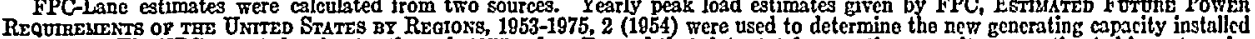

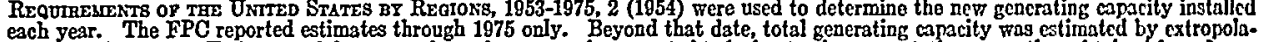
tion of FPC figures. Estimates of the proportions of new eapacity expected to be in atomic power stations pere then obtaincd from Lane, Grouth Potential of the U.S. Nuclear Poues Industry, Nucleonics, June 1954, p. 15, and new atomic power installed cach year pras calculated, from which the total atomic power capacity in each year was determined. Dr. Lane's cstimates were given through year $2000 \mathrm{~A} . \mathrm{D}$.

37 See 3 President's Materials Policy Conmmssion, op. cit. supra note 23, at 32.

${ }^{38}$ See FPC, Estimated Future Power Requirenents of the United States by Regions, I953I975, at 2 (I954).

39 See Edison Electrical. Institute, Looking Ahead to the Last Quarter of the First Centuny of Ezectric Power 7 (I954). 
conservative estimates of future nuclear power capacity, also shown in Table II. These estimates appear under the caption "FPC-Lane," for they draw from Federal Power Commission estimates combined with estimates by Dr. James A. Lane, Oak Ridge scientist.

\section{AEC Charges and Price Supports}

We have noted Mr. Davis' statement that the Commission will consider lending special nuclear (fissionable) materials to private power plants. As presented in the AEC demonstration program, the waiver of charges refers only to the interest charges and not to the cost of nuclear fuel produced at public expense and consumed by private power plants. ${ }^{40}$ Moreover, the law requires that for nuclear fuels consumed in commercial (but not research) facilities, the Commission must make a charge equal to either the cost (presumably total unit cost) of the nuclear fuels which it has produced or the average price it has paid others to produce them, whichever is the lower. ${ }^{41}$ This, of course, does not prevent the Commission from classifying early nuclear power stations as research rather than commercial facilitieswhich it is doing-but lends support to the expectation that undercharging for fuel elements will not be an important form of public aid..$^{4{ }^{a}}$ In the same vein, the Commission has agreed to furnish services of fuel element fabrication, chemical recovery of spent fuels, and other refining or processing operations at charges estimated separately for each job on the basis of recovery of full costs. ${ }^{42}$

Public aids have long been debated at the other end of power production, tooin connection with the Commission's buying back of nuclear fuels produced in private nuclear power plants. It is a well-known technological fact that plutonium, and perhaps the uranium isotope (U-233), will be produced in power plants at the same time that electricity is produced and at the same time that these or other fissionable materials are being consumed. ${ }^{43}$ Early attention, therefore, settled upon the concept of a "dual-purpose" reactor, which would produce both electricity and fissionable materials, the latter to be priced with reference to their value for weapons." An opposing school advanced the "single-purpose" reactor, whose virtue lay in the fact that fissionable materials produced as by-products of power genera-

${ }^{40}$ See AEC Release No. 589, Jan. Io, 1955.

«1 68 STAT. 930, 93 T, 42 U.S.C.A. \$\$2072, 2074 (Supp. 1954).

${ }^{41 a}$ As this article goes to press, it appears that the above expectation must be qualified. In remarks prepared for presentation before the Iowa Utilities Association, Des Moines, Ia., AEC Release, Oct. Io, 1955, W. Kenneth Davis, Director, Division of Reactor Development, AEC, stated: "The established prices [at which the Commission will lease fuel for reactors] were arrived at to reflect as well as possible the long-run true value of the materials purchased. Since the AEC is presently manufacturing some of these materials, prices were set to represent the savings in dollar expenditures by the Commission if the materials were produced by industry and purchased by the AEC, rather than if they were produced by the AEC." This means that until fuel materials are acquired by the AEC at the expected lower prices, public aid will result from this method of pricing the leased fuels.

"See the prepared statement read into the record by Kenneth D. Nichols, General Manager, AEC, in Hearings, supra note 13 , pt. I, at $74-75$.

${ }^{3}$ If nuclear fuels are being replaced more rapidly than they are being consumed in this process, we have what is known as "breeding."

"Sce Cisler, Economic Feasibility: The Dual Purpose Reactor, 290 AnNals 45 (Nov. 1953). 
tion would be priced only with reference to their value as fuel in further power generation (and further creation of replacement fuels). ${ }^{45}$

The AEC has expressed itself in favor of the single-purpose-reactor approach. The reasons, as given by W. Kenneth Davis, are twofold. ${ }^{46}$ The AEC takes the position that for the long-term future, it is best to conceive a civil atomic power industry not dependent, in any degree, upon military demands. ${ }^{47}$ Second, the AEC is committed to the single-purpose approach, as explained by Mr. Davis, because technologically a single-purpose reactor is qualitatively (not merely quantitatively) different from a dual-purpose reactor, and one must choose, at the present stage of the art, to develop in one direction or the other.

Information made public by AEC on its proposed pricing policy is limited out of consideration for national security. We have, however, the following statement which throws some light on specific features: $:^{48}$

r. The planned expenditures for weapon materials will not be increased for the benefit of nuclear power.

2. AEC will acquire special nuclear materials from licensees for subsequent distribution to other licensees and for other potential uses. The price structure gives effect to a consideration of value of these materials for intended use by the United States.

3. Prices for fuel grades of plutonium and $U_{-233}$ will be based on their value as nuclear fuels, competitive with $U_{-235}$, in a power-reactor economy.

4. Prices paid by AEC are subject to adjustment for the full cost of separations, recovery, etc., if the materials are in a form other than indicated in the price schedules.

5. The prices stated in the schedules are subject to adjustment for deviations from the specifications on which they are based.

6. Prices to be paid by AEC for special nuclear materials produced by licensees will be guaranteed for a period of 7 years, except for periodic adjustments if there are substantial changes in the Bureau of Labor Statistics Wholesale Price Index, excluding farm products and processed foods.

Points $I$ and 3 reflect the single-purpose approach, but, as if in contradiction to point 3 , point 2 opens the way for dual-purpose pricing. ${ }^{49}$ Point 6 provides a benchmark for planning private power plants. Until a private market has developed for special nuclear materials, there is no way to be sure what the single-purpose price will be. If such a price is envisaged in the seven-year guarantee, the AEC must

${ }^{45}$ See Weil, Economic Feasibility: The Single Purpose Nuclear Power Plant, id. at 50.

${ }^{10}$ See remarks prepared by W. Kenneth Davis, Director, Division of Reactor Development, AEC, for presentation before a meeting of Canadian Electrical Ass'n, Vancouver, B.C., AEC Relcase, Junc 29, I955.

I7 For a view, expressed in another context, that the defense program may extend for a period of time on the order of only ten years, see the testimony of Jesse C. Johnson, Director of Raw Matcrials, AEC, in Hearings, supra note $\mathrm{I} 3$, pt. $\mathrm{I}$, at $\mathrm{I3}$. . One is also reminded of the view held by Gordon Dean, exChairman of the Atomic Energy Commission, to the effect that at some point "not in the "unforesecable future," we shall have acquired all of the atomic weapons we shall possibly need, and at that time, we should cease to produce atomic weapons. See his remarks before the American Bar Association, San Francisco, Cal., AEC Release, Sept. I7, x952.

18 Prepared statement read into the record by Kenneth D. Nichols, in Hearings, supra note 13, at 74.

${ }^{40}$ For an explanation of the licensee status to which the pricing policy refers, see note 57 infra. 
take into account a wide variety of economic and technological considerations in estimating it. ${ }^{50}$ It is not known how the Commission proposes to use the BLS Wholesale Price Index.

Economically speaking, the single-purpose approach has much to recommend it. It forces the nuclear power industry to develop in a way that will make it selfsupporting in the absence of military demands, which may not, and we hope will not, continue to be important over the long run. As a technique of public aid, the Commission's alternative of financing research and development has a number of positive features to recommend it, as we have seen. These, in combination with the negative qualities of the dual-purpose approach, strongly support a policy in which public aid takes the form of research and development assistance rather than the stockpiling of bomb components.

\section{Atomic Power Stations}

The nation's first civil atomic power plant is scheduled to begin the production of electricity in 1957. This, of course, will be the pressurized water reactor at Shippingport, Pennsylvania, with a generating capacity of 60,000 kilowatts. The plant is financed in large part through AEC appropriations, as we have noted, in the five-year program. The Commission is spending $\$ 45$ million in related research and development and is providing the nuclear reactor and related equipment to the extent of $\$ 40$ million. The Duquesne Light Company, in a contract with the Commission, has agreed to provide the site for the nuclear reactor and furnish conventional generating facilities; to operate the reactor part of the plant and bear the labor costs thus entailed; to assume $\$ 5$ million of the cost of research, development, and construction of the reactor portion of the plant; and to pay the Commission for heat in the form of steam taken from the Commission's reactor..$^{51}$ Over a five-year period, the Commission estimates that Duquesne's purchases of energy from the reactor will total \$II.8 million. ${ }^{52}$ The cost of conventional electric generating equipment being furnished by Duquesne is approximately million. ${ }^{53}$ The Commission has estimated that the total of all of Duquesne's expenditures over the five-year period that is being used for amortization of the plant ${ }^{54}$ will be approximately $\$ 30$ million. ${ }^{65}$ In comparison with the $\$ 40$ million provided by the AEC, this means that for the power plant, the private electric power company is paying less than half, or about 43 per cent, of the total estimated costs. This, however, is not an unfavorable arrangement for the Commission in view of the costs of electricity from atomic

${ }^{00} 68$ STAT. 93I, 42 U.S.C.A. $\$ 2076$ (Supp. I954) prescribes the seven-year maximum in this guarantee.

"51 The Duquesne contract is described in Report, stipra note 12, Appendix B, at 24-25 (1954).

${ }^{62}$ Personal communication, Atomic Energy Commission, July 27, 1955.

${ }^{63}$ See Hearings, stipra note 13 , at 99.

"Defense mobilization Order VII-6, Amdt. 9, effective March 17, 1955, added a new expansion goal, No. 225, to its List III, entitling affected industries to accelerated tax amortization certificates. Goal No. 225 is for "Power facilities for military, atomic energy and defense related needs." See 20 FED. REG. I647 (March I8, 1955).

${ }^{\mathrm{G}}$ See Report, supra note I2, Appendix B. 
energy, which, we have seen, the Commission places at two to three times the level of conventional power.

The next two atomic power stations likely to be constructed have been proposed by the Detroit Edison Company and associates and by the Nuclear Power Group, led by Commonwealth Edison Company of Chicago. The proposals for these two plants were made upon an invitation of January Io, r955 by the Commission to American industry to submit proposals for full-scale atomic generating facilities. ${ }^{60}$ Approved proposals would become part of the Commission's Power Demonstration Reactor Program. A deadline of April I, I955 was set for the submission of proposals. Under the arrangements envisaged for the demonstration program, as has been seen, the Commission offered to provide assistance by: (I) waiving interest charges (which the AEC has set at 4 per cent) for the loan of source and special nuclear materials for a seven-year period beginning July $I$, I955; (2) performing in AEC laboratories without charge to participating firms certain mutually agreed upon research and development work; and (3) entering into research and development contracts with participating firms.

The last type of assistance would place the participating firms in a dual role. For their self-financed private activities in the demonstration program, the participating firms would hold AEC licenses, either section I03 licenses for the commercial use of special nuclear materials or section ro4 licenses for the private conduct of atomic research and development. ${ }^{57}$ As the Commission conceives the process, participating

${ }^{60}$ See AEC Release No. 589, Jan. ro, 1955.

${ }^{\text {ธ7 }} 68$ STAT. 936-38, 42 U.S.C.A. $\$ \$ 2133-34$ (Supp. 1954).

The key provisions for commercial ( $\$$ I03) licenses are:

(I) Licenses shall be issued on a nonexclusive basis;

(2) They shall be issued to applicants

(a) whose proposed activities will serve a useful purpose proportionate to the quantities of special nuclear material or source material to be utilized,

(b) who are equipped to observe and who agree to observe such safety standards to protect health and to minimize danger to life or property as the Commission may by rule establish, and

(c) who agree to make available to the Commission such technical information and data concerning activities under such licenses as the Commission may determine necessary to promote the common defense and security and to protect the health and safety of the public;

(3) Licenses shall be issued for specified periods, not to exceed forty years and are rencwable.

The key provisions for the research and development ( IO4 $\left._{4}\right)$ licenses are:

(I) The Commission is authorized to issue licenses for facilities involved in research and development leading to the demonstration of the practical value of such facilities for industrial or commercial purposes;

(2) In issuing licenses, the Commission shall impose the minimum amount of such rcgulations and terms of license as will permit the Commission to fulfill its obligations under the Act to promote the common defense and security and to protect the health and safety of the public;

(3) Such licenses will be compatible with the regulations and terms of license which would apply in the event that a commercial license were later to be issued pursuant to section I03 for that type of facility (reference is to facilities mentioned in item ( $I$ ) above); and

(4) Priority shall be given to facilities which the Commission feels will lead to major advances in the application of atomic energy for commercial or industrial purposes.

Regulations to implement these and related provisions of the 1954 legislation have been appcaring since April 1955. The list of topics upon which the Commission has or will soon issue regulations follows:

(I) Licensing of special nuclear material distribution;

(2) Licensing of utilization and production facilities; 
firms in the demonstration program will first operate under section I04 and then under section 103 licenses. ${ }^{58}$ The difference is a matter of degree. For that part of a participating firm's work carried out under a research and development contract, ${ }^{59}$ the information acquired would remain under the control of the Commission, subject to the same distributional program as obtains under traditional contracts generally employed by the AEC for research and development; the information in that other (privately financed) part of a firm's activities, however, could be privately controlled within the limits of patent rights, as these apply in the evolving civil reactor development field. ${ }^{60}$ To the extent that there is private investment in the demonstration program, the Commission feels that the anticipation of know-how and patent rights will have provided the incentive. ${ }^{61}$

The AEC criteria for evaluation of proposals under the demonstration program include: $(I)$ the probable contribution of the proposal toward economically competitive atomic power; (2) the cost to the AEC in funds and materials; (3) the risk to be assumed by private proposers; (4) the competence and responsibility of the proposers; and (5) assurances by proposers against abandonment. ${ }^{62}$

Four proposals were received under the January I0, I955 invitation with its

(3) Control of restricted data (as used by licensees, among others);

(4) Access to restricted data for civilian use;

(5) Licensing of operators-the individuals who manipulate the controls of a utilization or production facility;

(6) Licensing of distribution and use of byproduct material;

(7) Licensing of distribution and use of source material;

(8) Standards for radiation protection;

(9) Rules of practice (hearings);

(10) Prices to be paid by the Commission for special nuclear materials produced by licensees;

(II) Charges to be made by the Commission for certain materials, including special nuclear materials; and

(12) Criteria governing the use of commission facilities.

The overriding criteria in all of these regulations, it has been announced, is the necessity of the regulation for the protection of the public health and safety and for the national security. Cf. Remarks by Harold L. Price, Director, Division of Licensing, AEC, before the Atomic Industrial Forum, New York, AEC Release, May 24, 1955.

${ }^{68}$ See the testimony of Kenneth D. Nichols, in Hearings, supra note 13 , at 155 .

to The AEC has announced that the amounts to be paid under the contracts will be fixed in advance. See AEC Release No. 589, Jan. Io, 1955.

${ }^{\circ 0}$ There has been some question as to whether the legislative framers of the Atomic Energy Act of r954 intended to permit assistance of the type here described for firms holding $\$ \$ I_{03}$ or 104 licenses. The statutory provision in issue is $\$ 169$, which reads:

"No funds of the Commission shall be employed in the construction or operation of facilities

licensed under section $\mathrm{IO}_{3}$ or $\mathrm{IO}_{4}$ except under contract or other arrangement entered into pursuant to section 3r." 68 STAT. 952, 42 U.S.C.A. \$2209 (Supp. 1954).

Since the Commission proposes to contract for research and development under $\$ 3$ I (which deals with research assistance), the authority of the AEC to do this seems clear. But a number of members of the Joint Committee on Atomic Energy, including especially Representative Cole, have protested on the grounds that the exception in $\$ x 69$ was intended only to permit the AEC to contract for public use of private reactors at the convenience of the Government. The Commission's interpretation has been supported by other members of the Joint Committee, however, including especially Representative Holificld, and indications are that it will prevail. For the controversy, see Hearings, supra note 13, at $155-62$.

${ }^{1}$ See the testimony of Kenneth D. Nichols, in Hearings, supra note 13 , at 17I-72, I73.

${ }^{02}$ Sce AEC Release No. 589, Jan. 10, I955. 
April I deadline. Two of these, as we have noted, were made by groups of firms centering around the Detroit Edison Company and the Commonwealth Edison Company of Chicago. The other two were made by the Yankee Atomic Electric Company of Boston, with a membership constituted of twelve New England concerns, and by the Consumers Public Power District of Columbus, Nebraska. ${ }^{03}$ All of these groups had been holders of study agreements with the Commission for a number of years. Under no other circumstances could they have seriously proposed to commit funds to atomic power installations within the time limit. The AEC recognized the advantages held by firms already associated with the atomic energy program and noted that the situation was inevitable in view of the objective of rapid progress. ${ }^{\text {eq }}$

In announcing the four proposals, the Commission indicated that the four plants together would cost about $\$ 150$ million, 80 to 90 per cent of which would come from the proposers. ${ }^{65}$ The remaining $\$ \times 5$ to $\$ 30$ million would, if the AEC approved the projects, come in the form of assistance previously described for the demonstration program. Appropriations for this assistance, and apparently for assistance in later demonstration projects, were made, as we have noted, in the Acceleration of Civil Power item for fiscal year 1956 ( $c f$. Table I).

Several months later, in August 1955, the Commission disclosed that it had found that the Detroit Edison and Commonwealth Edison groups' proposals would make significant technological contributions and, hence, that negotiations were proceeding with these two groups. ${ }^{66}$ At the same time, the AEC revealed that the proposals by the Yankee Atomic Electric Company and Consumers Public Power District of Columbus, Nebraska, were judged to be unacceptable bases for negotiation as they then stood, although the door was left open for further discussion to determine whether they could be made acceptable. ${ }^{67}$ The Commission, of course, did not indicate how much financial assistance it might eventually agree to provide for the two technologically acceptable projects.

A final atomic power station under consideration by the Commssion at the time of this writing (August 1955) was proposed by the Consolidated Edison Company of New York in the winter months of 1955. Consolidated Edison's proposal is not a part of the demonstration program, for it involves no AEC assistance other than the grant of a license. Consolidated Edison proposes to build a nuclear power plant which it estimates will cost approximately $\$ 55$ million. ${ }^{68}$

The investment of private funds in atomic power stations is not explicable in terms of present reactor technologies. We have noted the present high cost of atomic power and the probable passage of time until it is expected to be competitive with

\footnotetext{
${ }^{83}$ See AEC Release No. 620, April 7, 1955.

"See the testimony of Chairman Strauss, in Hearings, supra note 13, at 25.

${ }^{65}$ See AEC Release No. 620, April 7, 1955.

${ }^{8}$ See AEC Release No. 674, Aug. 8, 1955.

${ }^{\circ}$ Ibid.

${ }^{88}$ See AEC Release No. 620, April 7, 1955.
} 
conventional power. Nor does it appear that the prospect of acquiring private patent rights would be sufficient incentive in view of both the magnitude of the private investment here involved and the length of time before such patent rights would become profitable. The answer, instead, seems to lie especially with certain ratemaking practices that have been or may be adopted by state public utility commissions. To the extent that such practices are adopted, we shall see that private atomic power installations in pre-competitive years will be financed at the consumer's expense.

The Detroit Edison Company and associates plan to build a roo megawatt fast breeder reactor plant within Detroit Edison's service area in Michigan. Detroit Edison will buy from the plant steam heat at a cost to be determined by a formula based upon the operation of a conventional steam plant and using as a criterion the company's most efficient generating plant. ${ }^{69}$ Thus, the nuclear power plant will lead to no higher electric power rates than would a modern conventional plant. This, however, is not the point at which the costs of the nuclear plant will be recovered. Detroit Edison has stated that it will furnish $\$ 5$ million of an esimated $\$ 45$ million for the construction of the plant. ${ }^{70}$ The other $\$ 40$ million is to be furnished by the other members of the group, numbering sixteen utilities and six manufacturing companies from ten different states and the District of Columbia. ${ }^{71}$ Detroit Edison has obtained an accounting order from the Michigan Public Service Commission authorizing it to reflect the $\$ 5$ million expenditure in the utility's Account 8or, Miscellaneous General Expenses. ${ }^{72}$ This means that in the normal course of events, the $\$ 5$ million will be charged to the Company's power cost pool, along with the cost of other electrical generation or power purchases, and that the total amount in this pool will be spread over all consumers. ${ }^{72 a}$ In the hearing preceding the Commission's order the petitioner made clear that the $\$ 5$ million, considered at a yearly rate of $\$ 11 / 4$ million and with allowance for income taxes, would not affect net revenue sufficiently in itself to bring an application for rate increases, but would, nevertheless, remain an element of value in general support of future rate increases. ${ }^{\mathbf{7 2}^{\mathbf{D}}}$

The Nuclear Power Group plans to build a I80 megawatt boiling-water-reactor plant about 44 miles southwest of Chicago, in a service area from which three of the member firms, Commonwealth Edison Co., Illinois Power Co., and Central Illinois Light Co. can draw electricity. Commonwealth Edison will own and operate the

${ }^{00}$ Letter from Michigan Public Service Commission to author, Aug. I r, I955.

${ }^{70}$ Ibid.

${ }^{71}$ The membership of the Detroit Edison group has expanded since the group's initial formation. As given in AEC EigrteENTH SEMIT-ANNUAL REP. 42 (July 1955 ), there were nineteen members in addition to the Detroit Edison Company. The list of members used here is from AEC Release No. 674, Aug. 8, 1955 .

${ }_{72}$ See Mich. Pub. Serv. Comm'n, Accounting Order D-1282A-55.I, March 23, 1955.

72a Letter from the Michigan Public Service Commission to the author, Aug. 26, 1955.

${ }^{72 b}$ See the testimony of Charles R. Landrigan, Vice-President, Detroit Edison Company, in Hearings before the Michigan Public Service Commission in the Matter of the Application of the Detroit Edison Company for Directions as to the Accounting Treatment for Disbursements Made or Expenses Incurred in the Design, Construction, and Operation of a Developmental Atomic Power Reactor 35, 39-42 (1955). 
plant and will pay $\$ 30$ million toward a $\$ 45$ million contract price for which the General Electric Company has agreed to build the plant. ${ }^{73}$ The $\$ 30$ million will enter Commonwealth Edison's plant accounts as a normal plant investment subject to customary practices for full recovery of fixed costs and a return on the value of the property. ${ }^{74}$ The remaining $\$ 15$ million will be paid by Commonwealth Edison and other members of the Nuclear Power Group, including six other electric utilities and one construction firm, the Bechtel Corporation of San Francico, which will act as engineering constructor for General Electric. ${ }^{74^{a}}$ In so far as the $\$ x_{5}$ million involves the three Illinois utilities, they have received authority to charge their contributions over a five-year period as operating expenses to Account 8or, Miscellaneous General Expenses, subject to the limitation that the amounts of such charges do not exceed $\$ 625,000, \$ 330,000$, and $\$ 110,000$ for Commonwealth Edison, Illinois Power, and Central Illinois Light respectively, in any twelve-month period. ${ }^{75}$

The inference seems clear that the other electric utility members of the Nuclear Power Group, representing two other states, will seek, or have sought, similar orders from their state commissions and that the far-flung utility associates of the Detroit Edison Company will do likewise. By letter, dated August 8, I955, the New York Public Service Commission advised the author that it had not taken any formal action with respect to the development, operation, or rate aspects of generation of electricity from nuclear installations. Involved in New York would be the Consolidated Edison Company, with its proposed independent nuclear power project, and members of both the Detroit Edison and the Nuclear Power Groups.

The process of financing pre-competitive nuclear power installations from expenses chargeable to electric rates in effect throws the risk of the research and development upon the consuming public, but without the same prospect of broad public benefit as attends research and development supported at federal expense. In the nature of things, electric utilities do not have and are not expected to have either the same organization for dissemination of information or the same techniques or responsibilities for representing the public interest as has the AEC. Present policy, perhaps developed in another context and, in any case, questionable for atomic power stations, however, explicitly permits the assignment of research and development expenditures to Account 8or in the uniform system of accounts which has been prescribed by the Federal Power Commission ${ }^{\mathbf{7 0}}$ and which has been adopted, in so far as this provision is concerned, by the Michigan, Illinois, and most other state regulatory commissions. And patent rights resulting from research and development so financed have, in the past, been acquired by the private electric utility.

The magnitude of the prospective investment in pre-competitive atomic power

${ }^{73}$ See Ill. Commerce Comm'n, Order No. 42638, July r9, 1955.

"Ibid.

74a For the membership of the Nuclear Power Group, see AEC Release No. 674, Aug. 8, 1955.

${ }^{75}$ See Ill. Commerce Comm'n, Order No. 42638, July 19, 1955.

${ }^{70}$ See Federal Power Commission, Order No. 42, Prescribing a System of Accounts for Public Utilities and Licensees under the Federal Power Act, June 16, 1936. 18 C.F.R. \$ror.00 (1949). 
facilities strongly suggests a reconsideration of this practice. The Detroit Edison and Commonwealth Edison applications for approval of a practice ostensibly well established suggest that the construction of a full-scale electric power station for the purpose of generating electricity at a cost two or three times the cost of alternative methods in order to advance technology is something of an extension of the research concept. But dangers are involved. To the extent that patent rights under the Atomic Energy Act I954 may accrue to electric utilities, these should be excluded from their intangible property accounts. Their inclusion would permit the capitalization of an asset already paid for through charges to operating expenses. On the other hand, even if so excluded, any such patent rights, acquired at public expense, might well have value either through sales to other utilities, which would necessarily be allowed to treat them as legitimate capital investments, or through sales on the open market. $^{7{ }^{2 a}}$ A related problem arises from the fact that the charges to Account 8or will be, at least in part, for physical plants. Such charges should not be capitalized any more than should patents arising from research paid for through the same operating expense account; but it will take careful administration to insure that the distinction will always be recognized when, for example, some parts of a plant, but not others, are charged to Account 8or, or when the value of a utility's property for rate making purposes is determined by appraisal.

Another public policy problem is posed by the $\$ 30$ million investment of Commonwealth Edison in its boiling water reactor plant. Traditionally, public regulatory bodies have hesitated to pass upon the merits of a technology embodied in a new investment. The matter is usually regarded as properly a concern of management alone, over which regulatory commissions do not want, and, in fact, generally lack the authority, to exercise control. This "hands off" approach has been supported by the popular assumption that new investments will follow least-cost techniques of production. Now we find that this assumption is fallacious to a marked degree in the atomic power plants in prospect. The justification for these plants, instead, is given in terms of the lessons that will be learned in operating them. This means that the real investment in technological progress is made, not by the utilities that own and operate the plants under traditional arrangements for recovery of their investments, but by the consuming public to the extent that it is asked to pay higher rates for electricity.

To be sure, the amounts involved in the nuclear plants now in prospect are small as compared with the total investment in the electric power industry, and the burden is spread more broadly by the practice of forming industrial groups. Moreover, there will undoubtedly be some private capital from nonreimbursable sources provided. The presence of non-utility members in the two power groups suggests this; and the possibility that the utilities themselves will invest out of retained

${ }^{70 a}$ The Detroit Edison Company has taken the position that it is not seeking patents from its atomic energy research. See the statement prepared by Harvey A. Fischer, Attorney for the Detroit Edison Company, in Hearings, stpra note $72 \mathrm{~b}$, at 7 . It is not known whether other utilities have taken the same position. 
earnings or another nonreimbursable source should not be excluded. Despite these facts, however, the precedent for financing through recoverable expenses may soon be firmly established, and if carried through the pre-competitive era of nuclear power, this will add a substantial increment to total power costs.

If it is necessary to build atomic power stations for the purpose of advancing reactor technology, an earlier proposal made by Dr. Hafstad in July 1954 has much to recommend it. Under this proposal, as we have seen, the AEC would share the costs of investment to the extent that atomic power costs exceeded conventional power costs, possibly as in the Duquesne Light project. The resulting technological knowledge would become public property, subject to the established AEC systems for dissemination of technological information. ${ }^{77}$

Expenditures upon atomic power stations that are reimbursed by consumers, plus any other payments by consumers for atomic power at a higher cost than conventional power, are probably best treated as public investments. The purpose, as we have seen, is to advance atomic power technology. Such investments by electric power consumers have a different incidence among members of the public than do AEC investments-this difference being especially dependent upon the location of atomic power plants and the membership of nuclear power groups-but with some simplification of concepts, they are equatable. This means that the two may be lumped together in estimating the grand total public investment in atomic power development. If public policy should return to Dr. Hafstad's suggestion of July 1954 for AEC support of the differential between atomic and conventional power costs, this would not change our total, though it would, of course, change the private property rights that could accrue to participating electric utilities. On the other hand, any private nonreimbursable capital investments in atomic power stations (not in other private research and development, which does not enter here) would have to be offset against the estimate we shall make. This means that our estimate will be a maximum that may be reduced by such private investments.

A rough approximation of the difference between the higher-cost atomic electricity and the cost of conventional power that would otherwise be produced from plants installed in the decade $195^{8-68}$ can be made as follows. Let us take certain figures given in October 1954 by Mr. Davis on the relationship between present-day nuclear reactor plants and future competitive nuclear plants. These figures show that the AEC hopes to attain competitive atomic power by reducing the construction cost of nuclear plants fourfold, increasing the length of their useful life one and a half times, and, by an interpretation of the figures, reducing over-all operating costs

\footnotetext{
77 The National Association of Railroad and Utilities Commissioners formed a Committee on Development and Use of Atomic Power in the Electric Industry, which requested and received AEC approval in July $x 953$ to obtain full security clearance to study the atomic power development program. Scc AEC Release No. 489, July 13, 1953. The problems here described would seem of special concern to the NARUC, but the author has been unable to learn of any announcement of the Committec's vicws.
} 
one and a half times. ${ }^{78}$ If we assume that atomic power will become competitive with conventional power at the beginning of the year I968, we can deduce from Mr. Davis' figures that for atomic power plants constructed in the ten-year span, I958-68, the deficit due to the use of atomic power will decline from 66.7 per cent of the total cost of all atomic power generated from the one plant in operation at the beginning of $195^{8}$ to zero per cent for the first new plant to operate in I968; and further, that the ratio of fixed cost to total cost per kilowatt-hour generated will decline from 66.7 per cent for the $195^{8}$ plant to 33.3 per cent for the first Ig68 plant. Next, we can approximate changes in physical plant costs from the fact, stated to the author, that competitive nuclear power is expected when plant costs have been reduced to $\$ 165-\$ 170$ per installed kilowatt. ${ }^{79}$ Let us assume that this level will be achieved in the first atomic plant to operate in rg68. Working back from this level, with the help of Mr. Davis' requirement for a fourfold reduction in plant construction costs, let us choose $\$ 670$ per installed kilowatt as a representative figure for atomic

${ }^{78}$ See Remarks prepared by W. Kenneth Davis, supra note 26 . The following table was set forth: Approximate Ratio of Costs Now Attainable to Costs Required for Economicality Competitive Nuclear Power

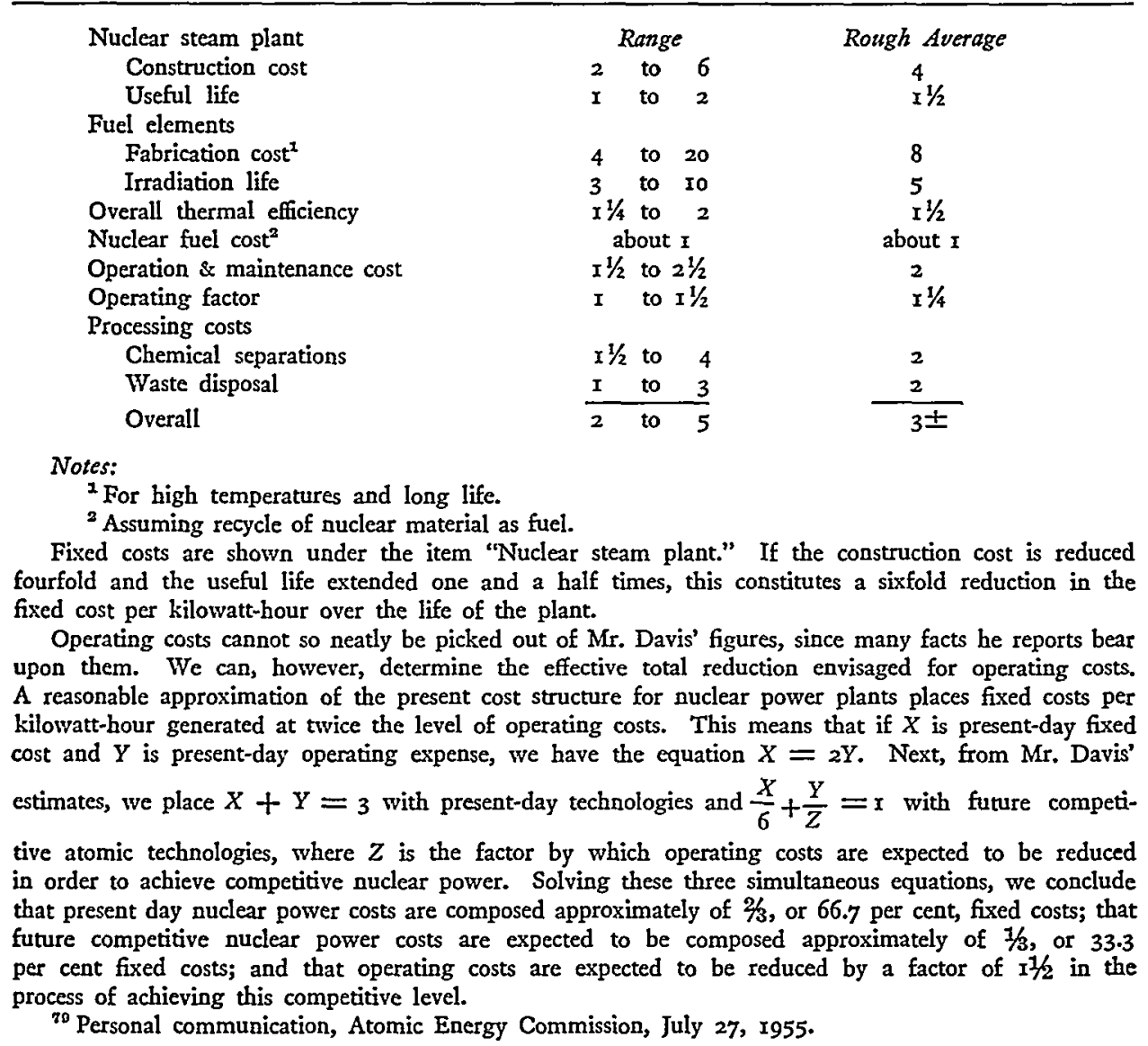


capacity coming into operation at the beginning of $195^{8 .} .^{80}$ For the sake of a rough approximation, let us now assume that these three changes-decline in deficit due to use of atomic power, change in ratio of fixed to total cost, and reduction in fixed cost per installed kilowatt-will take place in straight line relationships over the decade, and that the plant factors will remain the same in all atomic plants. Then, we can find the value for each of the three variables in each year, and, from the growth rates lying behind the estimates in Table II, we can get the nuclear capacity installed each year, which permits calculation of the deficit that will result over the life of the atomic facilities coming into operation during each year of the precompetitive decade. ${ }^{81}$ Summating these deficits gives a total public investment in atomic power stations of $\$ \mathrm{I} .4$ billion for the FPC-Lane growth estimates and $\$ \mathrm{r} .8$ billion for the Davis estimates. 82

\section{Public Benefits}

The reasons for the public effort in civil atomic power development have been explained in a number of ways by different atomic energy spokesmen. ${ }^{83} \mathrm{~A}$ consensus seems to place weight upon international as well as domestic economic benefits. The latter will be important for New England, Florida, the Dakotas, and other regions of high fuel cost in the years ahead, and more broadly significant in the late decades of the twentieth century when conventional fuels are expected to become more expensive. The former have been frequently associated with the present civil reactor effort

${ }^{80}$ The figure $\$ 670$ per installed kilowatt is more or less confirmed by what we know of the Duquesne plant. We have seen that the AEC is furnishing $\$ 40$ million for the nuclear reactor and related equipment. Duquesne Light Company's \$5 million is largely for research and development, while its $\$ 9$ million is for auxiliary conventional equipment. Taking only the $\$ 40$ million for the nuclcar reactor plant with its generating capacity of 60,000 kilowatts, we get a conservative estimate of $\$ 667$ per installed kilowatt.

${ }^{81}$ The deficit to result from atomic plants constructed in a given year, $i$, may be computed by the formula:

$\left(\begin{array}{l}\text { Atomic } \\ \text { Deficit, } \$\end{array}\right) i=\frac{\left(\begin{array}{l}\text { Deficit, } \$ \\ \text { Total cost of electricity, } \$\end{array}\right) i\left(\begin{array}{l}\text { Physical facilities } \\ \text { installed, } \mathrm{kw}\end{array}\right) i\left(\begin{array}{l}\text { Cost of physical } \\ \text { facilities installed, } \$ / \mathrm{kw}\end{array}\right) i}{\left(\frac{\text { Cost of physical facilities installed, } \$}{\text { Total cost of electricity, } \$}\right) i}$

${ }^{82}$ Most of the deficit for the Duquesne plant is excluded from these figures, since the largest part of it was covered by AEC expenditures (cf. Table I).

${ }^{83}$ The most significant public statements include the following: Rep. W. Sterling Cole, Chairman, Joint Committee on Atomic Energy, Development of Atomic Potver for Commercial Uses, address delivered before the National Industrial Conference Board, New York, N. Y., Oct. 29, 1953; Rep. Chet Holifield, Member, Joint Committee on Atomic Energy, The Hope of Electric Power from Atomic Energy, remarks before the National Rural Electric Cooperative Ass'n, Jan. 13, 1954; Henry D. Smyth, Member, AEC, Industrial Application of Atomic Energy, address delivered at the Third Annual Conference of Business Economists, University of Chicago, Chicago, Ill., April 23, 1954; Lcwis L. Strauss, Chairman, AEC, remarks before the Los Angeles World Affairs Council, April I9, I954; Lawrence R. Hafstad, Director, Division of Reactor Development, AEC, Industrial Atomic Power and lts Relation to Development of Other Natural Resources, remarks before the Missouri Basin Inter-Agency Committec, Rapid City, S. D., July 2I, r954; Thomas E. Murray, Member, AEC, Atomic Energy for Peace, address at the International Convention of the United Steelworkers of America, Atlantic City, N. J., Sept. 2I, 1954; W. Kenneth Davis, Director, Division of Reactor Development, AEC, Nuclear Pouver Industry Development, remarks at the Seventeenth Annual Meeting of the American Power Conference, Chicago, Ill., April I, 1955. 
in connection with the widely held conviction that the United States must lead in matters atomic, particularly where peaceful applications are involved. If low-cost atomic power reactors are developed first in this country, not only will it be a boon to national prestige, but it will also furnish an improved vehicle for concrete action in the aid of underdeveloped countries consistent with the President's Atoms-for-Peace proposal.

Domestic and international benefits are both responsible for the public investment in civil atomic power development, but it is beyond the scope of the present paper (and its author) to evaluate the international or to indicate more than some of the immediate domestic economic consequences. To this extent, however, an overall evaluation of the public investment in atomic power development is aided. An ample inventory of economic benefits, at least of the type that can be immediately foreseen, would allay any other public diseconomies, while a deficiency in the same area would make the more necessary favorable findings elsewhere.

We have estimated the AEC investment at $\$ 500$ to $\$ 600$ million through fiscal year 1958. There is the possibility that the AEC will continue to invest in civil reactor development in the decade $1958-68$, but no public spokesmen have encouraged the idea. The closest approximation that we have been able to make for this decade is a maximum investment in atomic power stations by electric power consumers of \$I.4 to $\$ \mathrm{I} .8$ billion. If we add the AEC to the electric consumers' investment, we obtain a grand total of approximately $\$ \mathrm{r} .9$ to $\$ 2.4$ billion for the public investment in atomic power development. To the extent that private capital itself assumes the differential higher cost of atomic power stations, these figures should be reduced. Apart from the public investment, private research and development efforts will undoubtedly pick up momentum in the chemical, electrical equipment, and other service and supply industries. ${ }^{84}$ All of these investments are chargeable, from the domestic economic standpoint, against savings in the cost of future electric power.

To illustrate the requirements of a write-off of the public investment, let us assume that starting upon January $\mathrm{r}, \mathrm{I} g 68 \mathrm{new}$ atomic power facilities will be built so as to generate electricity at a lower cost than new conventional steam power plants. Let us then postulate three possible levels for the cost saving: 2 mills, I mill, and $1 / 2$ mill per kilowatt-hour of electricity produced at the generating station, ${ }^{85}$ and postulate,

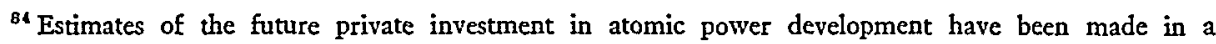
recent survey, Atomic Industrial Forum, A Growth Survey of THE Atomic Industry I955-I965 (1955). The Forum reports that industry and private organizations plan to spend \$300 million for research and development activities in the four years, 1954-1958. The estimates are not in a form from which we can determine the planned expenditures of electric utilities, but we know that the four demonstration-program proposals and the Consolidated Edison proposal under consideration at the time of the Atomic Industrial Forum survey totaled an investment of $\$ \times 75$ to $\$$ Igo million in non-AEC funds. See AEC Release No. 620, April 7, 1955.

${ }^{B 5}$ The average cost of power generated in plants accounting for approximately $80 \%$ of the national capacity of steam plant generation in 1953 was 8.06 mills per kilowatt-hour. The $80 \%$ includes electric capacity of both public and private steam plants but excludes plants judged obsolete by the FPC. For a group of the 25 largest steam generating plants in the United States, the comparable figure is 7.77
} 
further, that savings from the use of atomic power will continue at each of these respective levels over the years until the atomic power development investment has been completely retired in each case. For estimates of the atomic power capacity in existence in future years, we shall use the figures shown in Table II. Let us assume that both the Davis and FPC-Lane rates of growth will lead to competitive nuclear power at the beginning of 1968 . Within the accuracy of these capacity estimates, we cannot distinguish between probable rates of technological advance. Moreover, technological progress will be more dependent upon the variety of nuclear power installations than upon their number.

Our public investments in atomic power development accumulate interest at a compounded rate. Let us choose a rate of two and a half per cent as being roughly representative of the cost of the federal debt over the time span here involved and, hence, as roughly representing the value to the public of money used in atomic power development. Interest is compounded to reflect the fact that the public receives no interest payments as such, annual or otherwise, but must leave interest and principal, as it were, for retirement from eventual savings in the cost of atomic power. To simplify the calculation, let us assume that for the AEC investment through fiscal year $x 95^{8}$, the principal will be committed in such a way that, in effect, all costs can be considered to have been made upon the single weighted average date of January I, I957. For the grand total public investment, a date closer to I968 is in order, to take account, among other things, of a five-year period over which it is likely that consumers will pay for investments in atomic power stations, the arrangement proposed in the Detroit Edison and Nuclear Power Group projects. All things considered, let us select January $\mathrm{I}, \mathrm{Ig} 65$ as representing the effective date for the grand total public investment.

Following our previously stated assumption, retirement begins on January I, I968 and, with the cost savings we have postulated and the capacity estimates set forth in Table II, proceeds at a rapid enough rate to offset accumulation of interest. Table III shows the dates upon which the cost savings from atomic power would complete the retirement. Years of retirement are not shown for the \$I.9 billion public investment with the Davis estimates, since this investment was derived using the FPC-Lane estimates. The same reason, of course, explains the absence of years-ofretirement estimates for the $\$ 2.4$ billion principal with the FPC-Lane growth sched-

\footnotetext{
mills; and for a group of the $x 6$ largest hydro-electric generating plants, 3.04 mills. The first avemge was calculated from FPC, Steam-Eiectric Plant Construction Cost and Annual Production ExPENSES (I954). The calculations assumed a $60 \%$ plant factor and, as proposed in an unpublished study by the FPC dated February 1953, assumed an annual fixed charge equal to $11.7 \%$ of investment in physical plant. This fixed charge takes account of interest, depreciation, insurance, and taxes, including income taxes. The averages for the 25 largest steam and 16 largest hydro-electric plants were calculated from data reported in FPC ThIRTY-FourTy ANN. REP. 66-67 (1954). These calculations were based upon actually experienced plant factors of $57.5 \%$ in the 25 steam plants and $60 \%$ in the 25 largest hydro-electric plants, which included the 16 hydro-electric plants for which an average cost was determined. For the 25 largest steam plants, the annual rate of $11.7 \%$ was used for fixed charges, but for the 16 largest hydro-electric plants, an annual fixed charge rate of $10.7 \%$ was adopted, following unpublished data from the FPC.
} 
TABLE III

Retirement of Investment in Atomic Power Development

\begin{tabular}{|c|c|c|c|c|}
\hline \multirow{3}{*}{$\begin{array}{l}\text { Savings per } \\
\text { Kilowatt-Hour }\end{array}$} & \multicolumn{4}{|c|}{ Year of Retirement } \\
\hline & \multicolumn{2}{|c|}{ AEC Investment } & \multicolumn{2}{|c|}{ Total Public Investment } \\
\hline & $\begin{array}{l}\text { Principal } \\
\$ 500 \text { million }\end{array}$ & $\begin{array}{l}\text { Principal } \\
\$ 600 \text { million }\end{array}$ & $\begin{array}{l}\text { Principal } \\
\$ 1.9 \text { billion }\end{array}$ & $\begin{array}{c}\text { Principal } \\
\$ 2.4 \text { billion }\end{array}$ \\
\hline \multicolumn{5}{|c|}{ Davis Capacity Estimates } \\
\hline $\begin{array}{l}2.0 \text { mills } \ldots \ldots \ldots \ldots \ldots \ldots \\
1.0 \text { mill } \ldots \ldots \ldots \ldots \ldots \ldots \ldots \\
0.5 \text { mill } \ldots \ldots \ldots \ldots \ldots \ldots \ldots\end{array}$ & $\begin{array}{l}1973 \\
1975 \\
1976\end{array}$ & $\begin{array}{l}1973 \\
1975 \\
1977\end{array}$ & $\begin{array}{l}- \\
-\end{array}$ & $\begin{array}{r}1977 \\
1979 \\
\text { After } 1980\end{array}$ \\
\hline \multicolumn{5}{|c|}{ FPC-Lane Capacity Estimates } \\
\hline $\begin{array}{l}2.0 \text { mills } \ldots \ldots \ldots \ldots \ldots \ldots \\
1.0 \text { mill } \ldots \ldots \ldots \ldots \ldots \ldots \ldots \\
0.5 \text { mill. } \ldots \ldots \ldots \ldots \ldots \ldots \ldots\end{array}$ & $\begin{array}{l}1977 \\
1981 \\
1986\end{array}$ & $\begin{array}{l}1977 \\
1982 \\
1987\end{array}$ & $\begin{array}{l}1984 \\
1990 \\
1999\end{array}$ & $\begin{array}{l}- \\
-\end{array}$ \\
\hline
\end{tabular}

ule. For the total public investment, using the Davis estimates, with a rate of saving of 0.5 mill per kilowatt-hour, retirement would not take place until a few years after the last year included in these estimates.

From Table III, we can get some idea of the magnitude of the stakes involved, but our final judgment of what the figures portend for the public interest must be cast in the context of a number of qualifications. First among these is the possibility that a general increase in the use of atomic fuels will restrain an upward movement in the price of conventional fuels. This qualification could have the effect of shortening the time required for retirement of the public investment. Other matters, some of which we have noted in previous discussion, will make more difficult the establishment of low electric power rates on the basis of a given level of cost savings. ${ }^{86}$

Beyond the nuclear capacity estimates upon which Table III is based, any retardation in the real cost of conventional fuels as a result of the adoption of atomic fuels should be credited against the cost of research and development of the latter. There are logical bases for thinking that such a retardation will take place, but the extent of its effect upon conventional fuel prices is difficult to evaluate. The adoption of atomic fuels by electric utilities will reduce the demand for conventional fuels and, to this extent, delay any increases in their prices. The President's Materials Policy Commission found that in 1950 , electric power generation accounted for 23 per cent of the total national consumption of coal, 9 per cent of the gas, and 4 per cent of the oil, ${ }^{87}$ while it predicted that in 1975 , electric power generation would account

${ }^{80}$ For the professional economist, still other topics are of interest, though they do not change this analysis. See, e.g., Kuznets, Notes on the Quantitative Approach to Economic Growth, in Problems IN THE Study of Economic Growty Ix7 (National Bureau of Economic Research 1949); and Merlin, The Theory of Economic Change, 59 Q. J. Econ. I85 (I945).

${ }^{87}$ See 3 President's Materials Policy Commission, op. cit. supra note 23 , at 3, 16, 24,33 . 
for approximately 44 per cent of the nation's coal consumption; ${ }^{88}$ but it hesitated to predict total national gas or oil consumption from which the proportion pre-empted by electric power generation could be determined. ${ }^{80}$ The President's Commission anticipated no generation of electricity from atomic fuels in 1975 . It is clear that, at least in the market for coal, the extent of adoption of nuclear fuels shown by either the Davis or FPC-Lane estimates in Table II will significantly reduce total national demand below what it would be without atomic power. The price effects of this are not immediately obvious. We assume that coal technology will progress independently of atomic power development. The coming of nuclear power will take place over a period of decades, and, hence, in so far as its influence is concerned, conventional fuel output will have time to make long-run changes. Capital and manpower will have time to adjust. Since coal is a depletion industry, it is reasonable to expect that long-run cost changes would be upwards, but, beyond the immediate problems associated with a growing scarcity of beds minable by drift or slope entries and of deposits minable by strip methods, the President's Commission took the position that depletion of our national coal resources has not reached the point where long-run costs need to change significantly as a result of moderate expansions or contractions alone. ${ }^{90}$

The Table III figures would be influenced in the opposite direction by the appearance of private property rights in consumer-financed inventions. These would, as we have noted, prevent a full reflection of corresponding cost savings in consumers' electric power rates. Private property rights from risk-capital investments would have the same effect, but would be offset by the private research and development for which there had been no previous compensation and which might otherwise have been conducted at public expense. Such private investments will be made with the expectation of coverage by future cost savings in atomic power. Their presence will add to the total social investment in atomic power and, hence, to the total benefits necessarily expected from it.

From another standpoint, it is worthwhile to speculate as to whether the atomic investment need be as large as we have estimated it in order to get the same technological results. We have noted that the rate of progress in atomic power stations will depend more upon their variety than their number. The AEC applies this idea in approving projects for its demonstration program. Accordingly, it is not certain that we need have the volume of pre-competitive nuclear

\footnotetext{
${ }^{88}$ See I id. at $116,119$.

${ }^{80}$ In the decades after 1970 , when there is some prospect that coal may be used to make liquid fuels, the percentage used in electric power generation should again decline, whether or not we make an allowance for the use of atomic fuels. And if solar energy becomes as widely useful as some authorities suggest, the amount of electricity generated by both atomic energy and conventional fuels may fall below the expectations we have considered. See an address by Dr. James B. Conant, President of Harvard University and Honorary President of the Twelfth International Congress of Pure and Applied Chemistry, at the Ceremonial Session of the American Chemical Society Diamond Jubilce Meeting, New York, N. Y., Sept. 5, 195x.

${ }^{90}$ See 3 President's Materials Policy Commission, op. cit. supra note 23, at 24-26.
} 
power plants envisaged by either the Davis or FPC-Lane estimates. With respect to the AEC investment, the Commission is working along lines that it feels are most promising and, in so doing, seems to be seeking the best technological advice. The possibility exists, however, that a more leisurely approach, exploring one technological finding after another, might yield the same end results at a lower total cost. We know that the AEC is developing five different atomic power reactors. In addition, it is seriously considering expanding its efforts in two other directions.91 Indeed, Chairman Strauss has likened the present civil reactor development effort to the wartime Manhattan Engineering District "crash" program for the production of an atomic bomb.92 Mr. Strauss, of course, is not alone in his expressions of urgency. The importance of speed was reflected at the beginning of the current civil power effort in the Joint Committee's foreword to the initial public report on the five-year program. Referring to a meeting with the AEC, the foreword states: ${ }^{93}$

... the Commission assured the committee that, whenever possible, the entire 5-year program will be speeded up as a result of any new scientific or engineering advances.

The costs of speed appear in the aggregate values we have assigned to the public investment in atomic power development, but they also may appear as roadblocks to public benefit from that investment. We have adequately explored the problem presented by atomic development for public utility regulatory commissions. Another aspect of the matter appears in the industries expected to serve and supply atomic power stations. Prominent firms in the chemical and electrical equipment industries are AEC contractors of long standing for the operation of production reactors and the conduct of reactor-development work. Others in boiler manufacture, shipbuilding, metallurgy, and aircraft manufacture have long played a part in reactor-development activities. It is widely recognized that these firms have gained a considerable edge over their noncontract-holding rivals in experience or know-how, particularly since the national interest long required secrecy in certain phases of reactor development. The problem is now to bring other members of these industries into sufficient contact with reactor technologies so that they can compete effectively. Unless public policy adequately prepares for it, workable competition will not be established at this level and we cannot expect the prices for supplies and services available to electric utilities to reflect the full cost savings made possible by the public investment in nuclear power development.

The Commission has taken a number of steps to bring outsiders into contact with atomic technologies. These have mostly to do with the AEC study and access programs, which we cannot examine at this point except to note a few of their results. Prime contractors of the Commission in fiscal years 1955 and $195^{24}$ included from

${ }^{01}$ See Citrent Statement, supra note 12, at I0-11.

${ }^{02}$ See Hearings, supra note I3, at $149 .{ }^{93}$ See Report, supra note 12 , at iii.

0. Data for fiscal year 1955 are from Hearings before the Subcommittee of the House Committee on Appropriations on Independent Offices Appropriations for 1955, 83d Cong., 2d Sess., pt. 3, at 2567 (I954); data for fiscal year 1952 are from Hearings before the Subcommittee of the House Committee on Appropriations on Independent Offices Appropriations for 1953, 82d Cong., 2d Sess. II70-75 (1952). 
the chemical industry an unduplicated total of five firms in reactor operation or reactor development, four of which were among the nation's eight largest chemical firms; and from the electrical equipment industry, an unduplicated total of six firms, five of which were among the nation's eight largest in this industry. ${ }^{95}$ An adequate list of subcontractors in reactor development would moderate in some degree the impression given by these figures. But the important contrast is with study groups and access agreements, which, in combination, have brought in three more of the eight largest and ten to fifteen more of the smaller firms in the chemical industry. In the electrical equipment industry, no more of the eight largest appear among study-group members and access-permit holders, but five to ten other smaller electrical equipment firms are included. ${ }^{96}$ Access permits were first issued in April 1955, and by far the greatest number of firms represented in the above figures received their first contact with atomic technologies under these permits between April and the end of July I955, the terminal point for the information available at the time of this writing. Undoubtedly, access permits will continue to swell in number, but this is a late date for firms which have not previously been in reactor development to catch up with the years of experience gained by their larger rivals. Moreover, the latter have gained their experience or know-how while (for good reasons ${ }^{07}$ ) being reimbursed by the AEC and usually earning a profit as well.

The public interest in our national investment in atomic power development, as well as the continuing public interest in a competitive industrial society, requires redoubled efforts to bring broader participation in reactor technologies, at the expense of less rapid progress if necessary. We have suggested that a "crash" program in atomic power development might lead to higher expenses for the same technological knowledge than would a program conducted more deliberately. We now see that there is more at stake. If newcomers in the field do not have the chance to catch up competitively, through access agreements-or better, through participation-the technological fruits of progress will not be matched by commensurate advance in the general economic welfare.

\footnotetext{
${ }^{85}$ Size classifications follow FTC, Report on the Concentration of Productive Facilities, 1947 (1949).

${ }^{\circ 0}$ Members of study groups have been reported in the Commission's semiannual reports. Accesspermit holders through July r955 have been reported in AEC Releases Nos. 647, 66r, and 68x, of June Io, July 12, and Aug. 16, 1955. The figures here reported are somewhat indefinite because of the difficulty in classifying some of the firms.

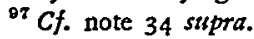

